\title{
Strategi Komunikasi “City Branding” Dalam Mengembangkan Potensi Pariwisata Kabupaten Kuantan Singingi Riau
}

\author{
Prima wahyudi ${ }^{1}$ Ismandianto $^{*^{2}}$, Yasir $^{3}$, Suyanto ${ }^{4}$ \\ Program Studi Ilmu Komunikasi, Fakultas Ilmu Sosial dan Ilmu Politik, Universitas Riau \\ Korespondensi : ismandianto@lecturer.unri.ac.id
}

\begin{abstract}
Abstrak
Penelitian ini bertujuan untuk mengetahui strategi komunikasi city branding dalam mengembangkan potensi pariwisata Kabupaten Kuantan Singingi Riau. Metode penelitian ini adalah menggunakan pendekatan deskriptif kualitatif. Peneliti memilih menggunakan paradigma konstruktivis karena ingin mendapatkan pengembangan pemahaman tentang City Branding. Penelitian terdiri dari beberapa tahapan, Tahap pengambilan data dilaksanakan dengan cara metode deskriptif kualitatif yaitu berupa Observasi, Wawancara, dan dokumentasi. Tahap Uji kredibilitas data dalam penelitian ini dilakukan dengan triangulasi teknik. Hasil penelitian ini adalah strategi komunikasi City Barnding, Proses penyampaian pesan terhadap citra yang dibangun melibatkan peran pemangku kepentingan, baik internal maupun eksternal seperti melibatkan peran generasi muda dalam hal ini adalah GenPI, para akademisi serta menjalin rekanan dengan media online dan cetak. Upaya yang ditempuh Pemerintah Kabupaten Kuantan Singingi adalah mengadakan pelatihan bagi SDM serta merencanakan alokasi anggaran untuk promosi pariwisata di APBD tahun berikutnya. Pola strategi komunikasi antara pemerintah daerah dengan komunitas cukup berjalan dengan baik, terbukti masih dialokasikannya anggaran untuk bidang-bidang tersebut meskipun belum maksimal. Kurang maksimalnya antara lain kurangnya sinergitas, penulis menilai hal ini dikarenakan adanya relasi kuasa yang menggeser potensi SDM yang ada.
\end{abstract}

Kata kunci : Strategi, Komunikasi, City Branding, dan Pariwisata.

\begin{abstract}
This research aims to find out the communication strategy " city branding" in developing tourism potential in Kuantan Singingi Riau Regency. This research method is to use a qualitative descriptive approach. Researchers chose to use the constructivist paradigm because they wanted to gain an understanding of City Branding. Research consists of several stages, the data retrieval stage is carried out by qualitative descriptive method in the form of Observation, Interview, and documentation. This study uses data credibility test to test the validity of data that has been obtained in the field. Data credibility test in this study was done by triangulation technique. The result of this research is City Barnding communication strategy, The process of delivering messages to the built image involves the role of stakeholders, both internal and external such as involving the role of the younger generation in this case is GenPI, academics and partnering with online and print media. The efforts taken by the Kuantan Singingi Regency Government is to conduct training for human resources and plan the budget allocation for tourism promotion in the next year's APBD. The pattern of communication strategy between local government and the community is quite running well, it is evident that the budget is still allocated for these areas even though it is not yet maximal. The lack of maximum, among others, lack of synergy, the author assesses this is due to the power relationship that shifts the potential of existing human resources.
\end{abstract}

Keywords; Strategy, Communication, City Branding, and Tourism. 


\section{PENDAHULUAN}

Pengembangan pariwisata dalam pembangunan ekonomi sangat penting di Indonesia dan semua negara. Laporan berbagai ahli menyimpulkan bahwa sumbangan pariwisata secara signifikan pada perkembangan ekonomi suatu negara atau daerah tampak dalam bentuk perluasan peluang bagi tenaga kerja di sektor pariwisata, peningkatan pendapatan (devisa), dan pemerataan pembangunan spasial (Damanik, 2013). Dinamika perkembangan pariwisata nasional sangat terlihat dari implikasi sektor ekonomi dan sosial serta kesejahteraan masyarakat (Ismandianto, 2019).

Indonesia memiliki potensi wisata yang besar dengan diperkuat oleh sumber daya manuasia dan sumber daya alam yang beraneka ragam di berbagai daerah. Salah satu daerah yang memiliki potensi dalam sektor pariwisata adalah daerah Kabupaten Kuantan Singingi. Sumber daya alam dan budaya yang dimiliki oleh Kabupaten Kuantan Singingi sangat potensial dikembangkan sebagai daya tarik wisata yang mampu menarik wisatawan baik nusantara maupun mancanegara. Pengembangan sektor pariwisata termasuk dalam mengembangkan perekonomian masyarakat yang berdaya saing guna meningkatkan kualitas hidup masyarakat dalam sektor pariwisata. Sasaran pokok misi tersebut terkait dengan pariwisata dijelaskan bahwa pertanian dan pariwisata menjadi basis sektor yang diprioritaskan guna kesejahteraan masyarakat, memberdayakan masyarakat, dan menghasilkan produk bernilai ekonomi.

Komunikasi pariwisata merupakan kegiatan yang dilakukan secara langsung agar bisa menyentuh dan berperanserta melibatkan masyarakat setempat. Salah satu potensi pariwisata adalah festival pacu jalur yang sudah masuk dalam agenda pariwisata nasional dan festival-festival lainnya serta potensi pariwisata alam, kuliner dan kreatif yang akan terus di kembangkan bisa menjadi peluang besar untuk dijadikan wisata budaya sebagai city branding bagi Kabupaten Kuantan Singingi dan sebagai peluang usaha ekonomi kreatif untuk meningkatkan pendapatan masyarakat Kabupaten Kuantan Singingi.

Daerah lain, Trend pencitraan kota kemudian bergeser menjadi bernuansa lokal-global, seperti Jogja Never Ending Asia, Solo The Spirit of Java, Semarang The Beauty of Asia, Enjoy Jakarta dan lain sebagainya. Kedua tipe trend jargon tersebut sejatinya memiliki tujuan yang sama, yaitu membangun brand (merk) atau identitas kota. Dengan identitas yang dimiliki, diharapkan orang dapat memberikan kesan (citra) positif terhadap kota tersebut, atau dengan kata lain mereka sedang melakukan pencitraan kota (city imaging). Salah satu upaya dalam meningkatkan ekonomi masyarakat adalah melalui "City Branding" merupakan kota yang menciptakan aspek ekonomi, sosial, cultural dan lingkungan memanfaatkan kesempatan dan masalah kota, mengubah kesempatan menjadi pemecahan (Landry, 2008).

Pariwisata betumpu pada keunikan, kekhasan, dan keaslian alam serta budaya yang ada dalam suatu masyarakat daerah (Ismandianto, Belli Nasution, 2020). Daerah dan Potensi pariwisata begitu besar di Kabupaten Kuantan Singingi ini di sertai keberadaan pacu jalur yang sudah sangat melekat di masyarakat perlu adanya upaya penguatan pariwisata melalui branding. Hal ini yang disebut dengan City Branding. Karena dengan branding ini akan mampu mengenalkan identitas pariwisata Indonesia dengan benar dan baik serta menyeluruh ke seluruh para wisatawan, baik wisatawan lokal maupun wisatawan asing (Meitaliza, 2018). 
Tabel 1. Data kelembagaan penunjang peristiwa kabupaten kuantan singing

\begin{tabular}{|c|c|c|c|c|}
\hline $\mathrm{NO}$ & $\begin{array}{c}\text { NAMA } \\
\text { LEMBAGA }\end{array}$ & $\begin{array}{l}\text { DIDIRIKAN } \\
\text { PADA TAHUN }\end{array}$ & $\begin{array}{l}\text { BERGERAK } \\
\text { DIBIDANG }\end{array}$ & $\begin{array}{c}\text { BEKERJA SAMA } \\
\text { DENGAN }\end{array}$ \\
\hline 1 & $\begin{array}{l}\text { Kelompok sadar } \\
\text { wisata Desa } \\
\text { Kasang }\end{array}$ & $\begin{array}{l}\text { SK Bupati } \\
23 / 11 / 2013\end{array}$ & $\begin{array}{l}\text { Sapta pesona } \\
\text { objek wisata }\end{array}$ & $\begin{array}{l}\text { Pemerintah } \\
\text { Kabupaten Sengingi }\end{array}$ \\
\hline 2 & $\begin{array}{l}\text { Kelompok sadar } \\
\text { wisata Desa } \\
\text { Pedusunan }\end{array}$ & $\begin{array}{l}\text { SK Bupati } \\
05 / 06 / 2012\end{array}$ & $\begin{array}{l}\text { Pengembang } \\
\text { an Area } \\
\text { Kebun Nopi }\end{array}$ & $\begin{array}{l}\text { Dinas Pariwisata dan } \\
\text { kebudayaan }\end{array}$ \\
\hline 3 & $\begin{array}{l}\text { Kelompok sadar } \\
\text { wisata desa Koto } \\
\text { Sentajo Raya }\end{array}$ & $\begin{array}{l}\text { SK Bupati } \\
07 / 07 / 2014\end{array}$ & $\begin{array}{l}\text { Pengembang } \\
\text { an dan } \\
\text { Pemeliharaan } \\
\text { rumah adat }\end{array}$ & $\begin{array}{l}\text { Dinas Pariwisata dan } \\
\text { kebudayaan } \\
\text { Kabupaten Kuantan } \\
\text { Singingi }\end{array}$ \\
\hline 4 & $\begin{array}{l}\text { Ikatan pemuda } \\
\text { pacu jalur dan } \\
\text { informasi } \\
\text { Kabupaten } \\
\text { Kuantan } \\
\text { Singingi }\end{array}$ & $\begin{array}{l}\text { Launcing } 2017 \\
\text { melalui apresiasi } \\
\text { yang diberikan } \\
\text { oleh bupati }\end{array}$ & $\begin{array}{l}\text { Mempublikas } \\
\text { ikan budaya } \\
\text { event tahunan } \\
\text { pacu jalur } \\
\text { serta } \\
\text { destinasi } \\
\text { wisata } \\
\text { Kuansing }\end{array}$ & Pihak swasta \\
\hline 5 & $\begin{array}{l}\text { Kelompok sadar } \\
\text { wisata desa } \\
\text { Lubuk } \\
\text { Ambacang }\end{array}$ & $\begin{array}{l}\text { Pada tanggal } 15 \\
\text { Maret oleh Pijar } \\
\text { Melayu }\end{array}$ & $\begin{array}{l}\text { Pengembang } \\
\text { an dan sapta } \\
\text { pesona objek } \\
\text { wisata }\end{array}$ & $\begin{array}{l}\text { Pihak swasta yakni } \\
\text { pijar melayu } \\
\text { (Lembaga swadaya } \\
\text { masyarakat) }\end{array}$ \\
\hline
\end{tabular}

Sumber: Pendataan Bidang Pariwisata tentang kelembagaan pendukung kepariwisataan tahun 2020

Berdasarkan penelitian (Dyas 2016) mengkaji ulang mengenai visi dan strategi yang berhubungan dengan branding kota sebagai pintu gerbang budaya Melayu, dan melakukan sinergi antar stakeholders agar tercipta kerja sama yang baik. Penelitian oleh (Yasir 2019) menunjukkan bahwa kebijakan pariwisata di Kabupaten Bengkalis didasarkan pada undang-undang dan peraturan pemerintah pusat yang bersinergi dengan pemerintah Provinsi Riau. Penelitian (Vani,2020) potensi wisata di Kota Pekanbaru dapat berkembang dengan pesat apabila seluruh stakeholder berkolaborasi antar unsur dengan baik dihasilkan model pentahelix. Penelitian (Romli, 2020) "Bandung Juara" sebagai bagian dari city branding Kota Bandung diinternalisasi oleh pemerintah serta masyarakat melalui berbagai program seperti menggalakan bersepeda, musrenbang, mempermudah izin usaha, relawan kebersihan dan penataan taman kota.

Komonitas sadar wisata atau kepariwisataan di Kabupaten Kuantan Singingi saat ini masih sangat terbatas baik kulitas maupun kuantitasnya. Hal ini karena kepariwisataan di Kabupaten Kuantan Singingi secara umum masih dalam tahapan perintisan. Komunitas yang konsern dan fokus pada pengembangan pariwisata adalah Komunitas Generasi Pesona Indonesia (GEMPI) untik mempromosikan pariwisata Kuantan Singingi kepada masyarakat luas secara nasional maupun internasional melalui media digital, Sosial media dan komunitas pecinta pariwisata. Berdasarkan latar penelitian permasalahan diatas, penelitia mengkaji bagaimana Strategi Komunikasi "City Branding" dalam Mengembangkan Potensi Pariwisata di Kabupaten Kuantan Singingi Riau. 


\section{METODE}

Penelitian ini dilaksanakan di Kabupaten Kuantan Singingi, pemilihan lokasi ini disebabkan masih samarnya informasi mengenai strategi komunikasi dalam hal City Branding di daerah tersebut. yang berlangsung selama tujuh bulan dari bulan November 2019 sampai Maret 2020. Tahap pengambilan data dilaksanakan dengan cara metode deskriptif kualitatif yaitu berupa Observasi, Wawancara, dan dokumentasi. Dimana Paradigma yang digunaka dalam penelitian ini adalah paradigma konstuktivis.

Pemilihan paradigma konstruktivis karena ingin mendapatkan pengembangan pemahaman tentang City Branding dalam mengembangkan potensi pariwisata Kabupaten Kuantan Singingi yang dianggap memiliki kajian yang unik dan menarik untuk di teliti sehingga menghasilkan strategi komunikasi yang dapat membantu serta memiliki manfaat bagi semua kalangan.

Selain itu penentuan informan dalam pengambilan data dilakukan secara purposive, penentuan informan dengan cara menetapkan kriteria yang sesuai dengan tujuan penelitia untuk dapat menjawab permasalahan penelitian. Objek penelitian yaitu strategi Komunikasi "City Branding" Pemerintah Kabupaten Kuantan Singingi Dalam Mengembangkan Potensi Pariwisata. Uji kredibilitas data dalam penelitian ini dilakukan dengan Triangulasi, diartikan sebagai pengecekan data dari berbagai sumber dengan berbagai waktu. (Sugiyono, 2016).

Peneliti memilih teknik ini dikarenakan peneliti menggunakan tiga elemen pengumpulan data yakni observasi, wawancara, dan studi dokumentasi. Triangulasi data digunakan agar peneliti dapat melihat seberapa jauh keabsahan data yang peneliti peroleh pada saat penelitian di lapangan.

\section{HASIL DAN PEMBAHASAN}

\section{Gambaran Umum Kabupaten Kuantan Singingi}

Secara geografis Kabupaten Kuantan Singingi berada tepat diperlintasan antara Kota Pekanbaru, Jambi dan Padang tepatnya di 00 00'-1000' Lintang Selatan dan 101002'-101055' Bujur Timur. Letaknya yang berada diperlintasan jalur lintas sumatera menempatkan Kabupaten Kuantan Singingi memiliki keunggulan aksesibilitas yang relative bagus. Secara umum Kabupaten Kuantan Singingi berada diketinggian antara 25-30 mdpl dengan luas mencapai 7.656,03 Km2. Kabupaten Kuantan Singingi sesuai dengan namanya merupakan gabungan nama dua buah sungai yang melintas di kawasan ini yaitu Sungai Kuantan dan Sungai Singingi. Visi Pemerintah Kabupaten Kuantan Singingi Tahun 2016-2021 adalah: "Terwujudnya Kabupaten Kuantan Singingi yang Unggul, Sejahtera, dan Agamis di Provinsi Riau Tahun 2021".

Dinas Pariwisata dan Kebudayaan Kabupaten Kuantan Singingi dalam Rencana Pembangunan Jangka Menengah Daerah (RPJMD) 2016-2021 diamanatkan bahwa arah pengembangan dan pembangunan yang ingin dicapai sebagai "Daerah Tujuan Wisata Terkemuka di Provinsi Riau" yang berbasis Budaya akan mampu menciptakan kegiatan ekonomi yang terus meningkat sehingga mampu menarik para pelaku usaha untuk berinvestasi. Fasilitas makan dan minum dalam Peraturan Menteri Pariwisata Nomor 18 Tahun 2016.

\section{Strategi komunikasi city branding dalam mengembangkan potensi pariwisata}

City branding merupakan salah satu upaya pemerintah untuk mendapatkan legitimasi secara luas bahwa daerah tersebut unggul dalam aspek yang dipromosikan atau yang di citrakan. Dalam kajian ini, penulis mengambil promosi dari Potensi Pariwisata Kabupaten Kuantan Singingi sebagai Objek Penelitian. Penelitian ini menggunakan paradigma konstuktivisme dalam pendalamannya, dimana 
Paradigma konstruktivisme ialah paradigma dimana kebenaran suatu realitas sosial dilihat sebagai hasil konstruksi sosial, dan kebenaran suatu realitas sosial bersifat relatif.

Paradigma konstruktivisme ini berada dalam perspektif interpretivisme (penafsiran) yang terbagi dalam tiga jenis, yaitu interaksi simbolik, fenomenologis dan hermeneutik. Dalam penyampaian pesan terhadap khalayak secara luas, peran komunikasi sangat membantu pemasaran pariwisata diberbagai elemen pemasaran, maupun konten komunikasi. Di media komunikasi, tersedia berbagai macam media komunikasi sebagai saluran pemasaran, destinasi, aksesibilitas maupun saluran media SDM dan kelembagaan pariwisata. Komunikasi juga berperan menyiapkan konten pesan yang harus disampaikan kepada masyarakat atau, tentang apa yang seharusnya mereka tahutentang media-media pemasaran, tentang destinasi, aksesibilitas dan SDM serta kelembagaan pariwisata.

Dari hasil yang telah didapat dari penelitian yang penulis lakukan, penggunaan media baru dalam pengaplikasiannya berjalan dengan semestinya, dimana menurut Rogers dalam Anis Hamidati menguraikan tiga sifat utama yang menandai kehadiran teknologi komunikasi baru, yaitu interactivity, de-massification, dan asynchronous. Interactivitymerupakan kemampuan sistem komunikais baru (biasanya berisi sebuah komputer sebagai komponennya) untuk berbicara balik (talk back) kepada penggunanya. Hampir seperti seorang individu yang berpartisipasi dalam sebuah percakapan. Dalam ungkapan lain, media baru memiliki sifat interaktif yang tingkatannya mendekati sifat interaktif pada komunikasi antarpribadi secara tatap muka (Hamidati, Anis, 2011).

City branding yang ditanamkan pada kabupaten ini adalah Kuantan singingi sebagai kota destinasi pariwisata, baik pariwisata alam maupun pariwisata budaya. Menurut hasil penelitian yang telah penulis lakukan, untuk melihat City Branding, mengacu pada beberapa aspek, yaitu :

1. Poduct, memperkenalkan Kabupaten Kuantan Singingi Sebagai Tempat Tujuan Wisata. Perkenalan ini ditempuh pemerintah daerah dengan cara merangkul pelaku usaha, akademisi serta komunitas. Hal ini dilakukan agar perkenalan pariwisata terhadap masyarakat secara luas, baik nasional maupun internasional terlihat matang dan tidak terkesan asal-asalan.

2. Price, Harga yg dimaksud adalah murahnya biaya untuk dapat mengakses tempat-tempat wisata. Pemerintah daerah berupaya untuk menekan biaya agar wisatawan tidak perlu merogoh kocek yang berlebihan untuk bias menikmati tempat-tempat wisata. Dalam penelitian yang dilakukan, penulis melihat bahwa tidak adanya pungutan biaya untuk memasuki tempat-tempat wisata.

3. Place, dalam hal ini dikamksudkan pada sektor distibusi, dimana pemerintah memperkenalkan tempat-tempat destinasi wisata melalui peta wisata, buku, website, dan media social, sehingga wisatawan dapat dengan mudah mengetahui bahwa di kabupaten Kuantan Singingi terdapat banyak tempat wisata yang wajib dikunjungi.

4. Promotions, meningkatkan promosi dan publikasi wisata kabupaten Kuantan Singingi melalui beragam media, dengan tolak ukur efektif, efisien, inovatif dan tepat sasaran. Prihal promosi menjadi cukup meningkat. Karna komunitas pariwisata yang berbasis pada zona milenial, dalam hal ini adalah GenPI, dimana GenPi melakukan publikasi di berbagai media social. 
Gambar 1. Pelantikan Komunitas GenPI

ส Home / Hot News / Komunitas GenPI Kuantan Resmi Dikukuhkan

\section{Komunitas GenPI Kuantan Resmi Dikukuhkan}

触 18 Juli 2019 14:23 ¿ Heru Maindikali

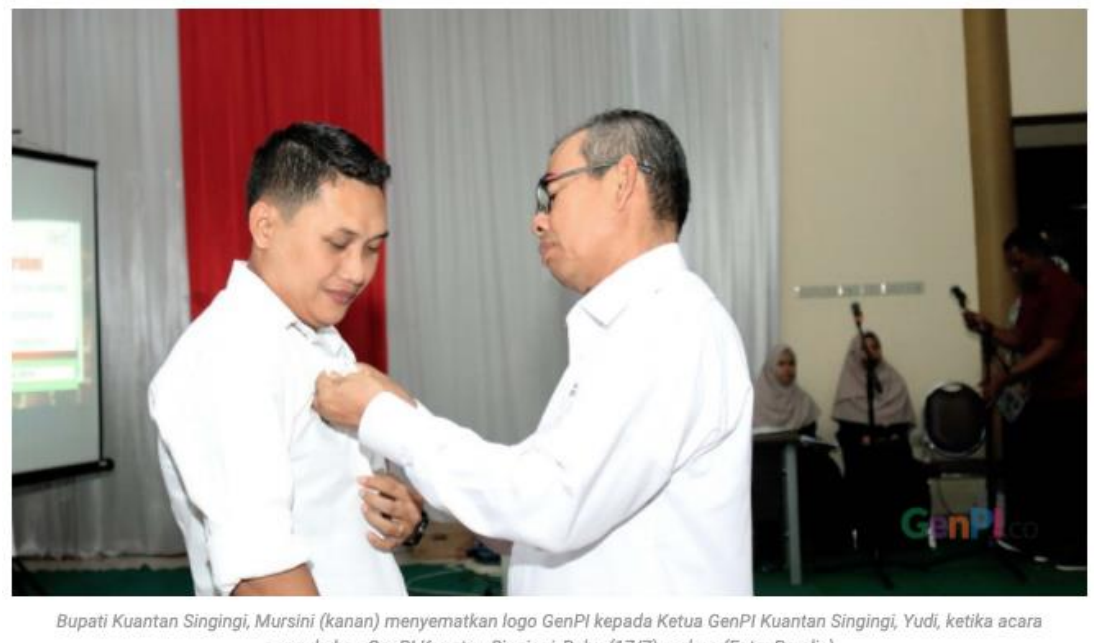

pengukuhan GenPI Kuantan Singingi, Rabu (17/7) malam. (Foto: Ramlis)

GenPI.co - Bupati Kuantan Singingi, Mursini, kukuhkan pengurus Generasi Pesona Indonesia (GenPI) Sub regional Kabupaten Kuantan Singingi, provinsi Riau. Pengukuhan berlangsung di Pendopo rumah dinas Bupati Kuansing, Rabu (17/7) malam.

Sumber: website GenPI.co

Gambar diatas merupakan salah satu bentuk nyata pemerintah daerah dalam merangkul komunitas untuk turut serta dalam mengembangkan pariwisata, yakni dengan di resmikannya komunitas GenPi. Kemudian, lebih jauh lagi, pandangan pemerintah untuk melakukan City Branding juga berjalan lurus dengan pendapat Handito (Sugiarsono, 2009) mengenai alasan melakukan City Branding, yaitu :

a. Memperkenalkan daerah tentang keindahan kota, potensi dan kekayaan yang belum diketahui oleh masyarakat dengan city branding sehingga membuat orang tertarik dan ada keinginan untuk mengunjunginya.

b. Memperbaiki citra kota, secara positif dengan menonjolkan potensi sehingga terkadang orang melupakan citra yang kurang baik dari kota tersebut sebelumnya.

c. Menarik wisatawan, sehingga dengan city branding akan menarik wisatawan datang ke kota tersebut karena memiliki ciri khas tersendiri.

d. Investor atau berinvestasi, membuka peluang kemajuan perekonomian dari sisi pariwisata sehingga akan membuat investor juga tertarik untuk berinvestasi.

e. Meningkatkan sektor perdagangan yang menyediakan berbagai bentuk oleh-oleh ciri khas daerah tersebut.

\section{Pengembangan Potensi Sektor Wisata Kabupaten Kuantan Singingi dalam Pembentukan City Branding}

Kabupaten Kuantan Singingi merupakan suatu daerah yang kaya akan budaya dan tradisi seperti Air Terjun Guruh Gemurai, Air Terjun 7 Tingkat Batang Koban Batang Koban di Hulu Kuantan, sumber air panas di Sungai Pinang Hulu Kuantan, danau kebun Nopi di Kuantan. Mudik, danau mesjid Koto Kari serta berbagai wisata budaya seperti lomba perahu bagandung di Lubuk Jambi, tradisi menangkap ikan di lubuak larangan di Desa Pangkalan Indarung Kecamatan Singingi, mandi balimau yang hampir disetiap daerah Kuantan Singingi, silat tradisional di Pangean, wisata ziarah kubur dan berbagai macam 
permainan adat seperti : Randai, gasing, sepak rago tinggi, gilo luka, rarak godang, salah satu pariwisata terpopuler di Kabupaten Kuantan Singingi yaitu pacu jalur.

a. Komunikasi Pariwisata

Dalam hal ini, penulis menemukan bahwa komunikasi pariwisata yang dilakukan oleh pemerintah daerah antara lain adalah membangun citra destinasi wisata yang terhubung dengan sejarah lokal, jadi destinasi yang dibangun tidak hanya mengandalkan pemandangan alam atau bentuk fisik saja, melainkan nilai-nilai historis yang terkandung di dalamnya, sehingga destinasi wisata tersebut tidak terpaku sebagai objek fisik, namun juga sebagai medium komunikasi dari pariwisata tersebut. Kemudian objek-objek wisata tersebut disadur kedalam medium digital seperti media social untuk mendistribusikan nilai dan pesona pariwisata.

b. Di dalam kajian ini, prinsip-prinsip manajemen komunikasi menjadi ulasan-ulasan penting yang dilakukan dan diterapkan di bidang komunikasi pariwisata. Kajian ini mengulas mengenai bagaimana manajemen diterapkan di bidang komunikasi pariwisata, yaitu bagaimana memenejemen pemasaran pariwisata, memenejemen destinasi, memenejemen asesibilitas dan memenej SDM serta kelembagaan pariwisata. Bagaimana peran pimpinan dan leadership, bagaimana memenej orang-orang, memenej anggaran dan memenej alat-alat dan mesin komunikasi pariwisata. Terpenting pula di sini bagaimana memenej berbagai macam saluran saluran media komunikasi yang digunakan di dalam komunikasi pariwisata.

\section{Pola Strategi Komunikasi antara pemerintah kabupaten Kuantan Singingi dengan komunitas dalam pemberdayaan masyarakat}

\section{a. Komunikasi Digital Pariwisata}

Dalam hal ini adalah media baru (new media), dapat digunakan untuk promosi dan informasi dalam dunia pariwisata. Di dalam kajian ini pula dibincangkan tenteng media baru (new media), media online baru (new media online), diverifikasi media, media metafora, dan semiotika media serta media virtual yang dapat diaplikasikan ke dalam komunikasi pariwisata. Aktor utama yang dirangkul pemerintah dalam misi promosi digital adalah Dinas Pariwisata, Dinas KOMINFOSS serta GenPi.

b. Media Langsung dan Tidak Langsung

Media komunikasi yaitu penyampaian informasi secara langsung, atau bertatap muka secara langsung. Komunikasi yang digunakan antara lain mengadakan rapat, diskusi serta kunjungan kerja ke berbagai daerah.

Beragam kegiatan rapat rutin dilakukan pemerintah daerah sebagai bentuk koordinasi antar instansi, pelaku usaha, komunitas, insane media (cetak dan online) serta akademisi untuk menyampaikan program serta progres dari promosi dan perkembangan pariwisata di daerah Kabupaten Kuantan Singingi. 
Gambar 2. Kegiatan Pemerintah Daerah dalam Wisata Kuantan Sengingi

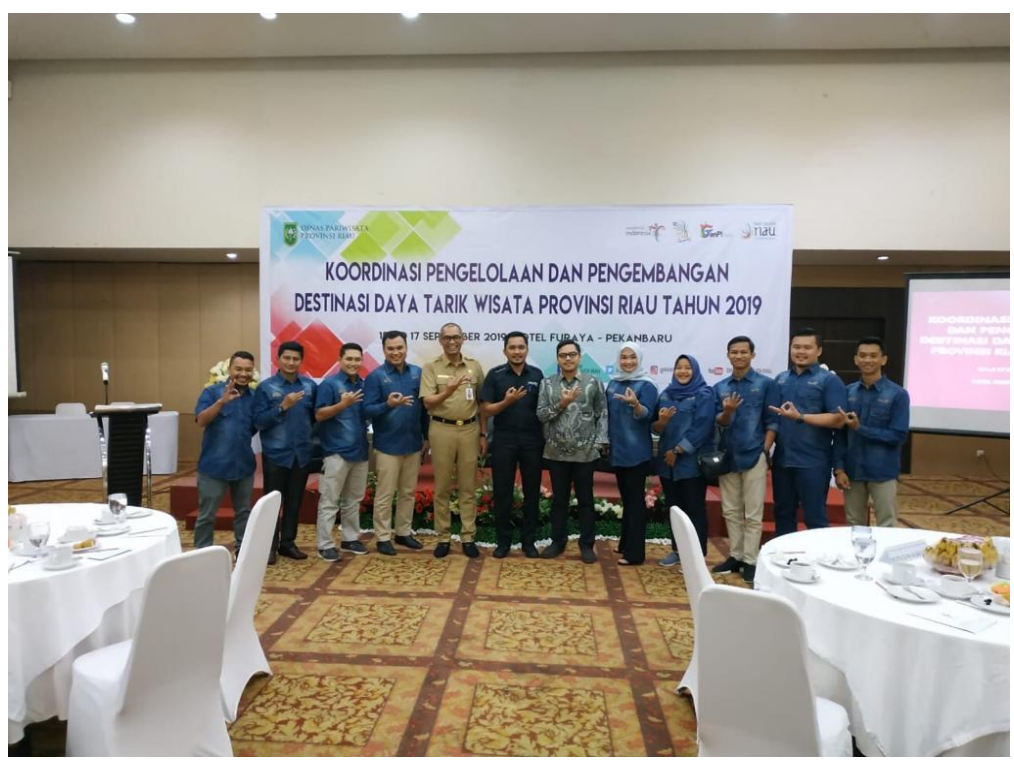

Sumber: Dokumentasi peneliti, 2019

Dari beberapa gambar diatas, menunjukkan bahwa pola kerjasama yang dilakukan pemerintah salah satunya dengan merangkul komunitas, serta mengadakan rapat untuk perencanaan dan pengaplikasian terhadap rencana promosi dan pengembangan pariwisata daerah.

Media komunikasi tidak lengsung merupakan media komunikasi dengan menggunakan sarana alat bantu tertentu. Media komunikasi yang digunakan antara lain spanduk, baliho, surat dan New Media. Instansi terkait yang menjalankan hal ini adalah Dinas KOMINFOSS dan dinas Pariwisata, dimana instansi ini menggunakan New Media dalam memberikan informasi publik, baik melalui website, instagram, Facebook, dan Youtube.

Kemudian pemerintah melibatkan komunitas yang bergerak dibidang pariwisata, salah satunya adalah GenPI, GenPI dipandang mumpuni oleh pemerintah dalam hal publikasi secara masive melalui media sosial, karena GenPI memiliki jejaring sosial yang luas di indonesia. Dalam hal ini, pemerintah daerah telah menjalin kerjasama dengan GenPI, dimana genpi account media sosial yang cukup banyak diikuti oleh masyarakat Kuantan Singingi, terutama para generasi muda dan mereka yang melek akan media. Efektifitas dari penyebaran informasi yang dilakukan KOMINFOSS beserta turunan dibawahnya, secara berkala dapat membuahkan hasil yang diharapkan.

Berangkat dari rasa ingin tahu masyarakat terhadap postingan informasi pariwisata yang di publikasikan oleh akun-akun tersebut. Kemudian masyarakat atau khalayak yang melihat postingan mendatangi tempat tempat wisata yang dipublikasikan. Dengan kata lain, akun-akun media sosial tersebut berperan sebagai Buzzer pemerintah untuk mendistirbusikan informasi, lalu informasi tersebut tersebar ke masyarakat (viral), dan semakin meluas secara estapet dari mulut ke mulut.

Upaya yang ditempuh Pemerintak Kabupaten Kuantan Singingi dalam menjawab kendala mempromosikan pariwisata daerah diantaranya adalah mendorong kapasitas SDM. Kendala pada kapasitas SDM bidang pariwisata serta Hospitality, dalam hal ini pemerintah menjawab dengan cara melakukan pelatihan secara berkala

Serta memberi peluang pada generasi muda serta masyarakat yang memiliki kompetensi dalam hal tersebut, tentunya dengan beragam step perekrutan. Pemerintah juga berupaya untuk 
memberikan alokasi anggaran tambahan dibidang pariwisata, baik itu akses transportasi serta publisitas pada RAPBD berikutnya.

\section{KESIMPULAN}

Berdasarkan dari hasil penelitian dan pembahasan, disimpulkan strategi komunikasi "city branding" dalam mengembangkan potensi pariwisata di Kabupaten Kuantan Singingi dilakukan dalam beberapa rangkaian : Pertama, Dalam prihal strategi komunikasi City Barnding, Proses penyampaian pesan terhadap citra yang dibangun melibatkan peran pemangku kepentingan, baik internal maupun eksternal seperti melibatkan peran generasi muda dalam hal ini adalah GenPI, para akademisi serta menjalin rekanan dengan media. Kedua, Pengembangan potensi sektor wisata dalam mendukung pembentukan City Branding antara lain promosi melalui media langsung dan tidak langsung. Dan, ketiga, pola strategi komunikasi antara pemerintah daerah dengan komunitas cukup berjalan dengan baik, terbukti masih dialokasikannya anggaran untuk bidang-bidang tersebut meskipun belum maksimal. Kurang maksimalnya antara lain kurangnya sinergitas, penulis menilai hal ini dikarenakan adanya relasi kuasa yang menggeser potensi SDM yang ada.

\section{SARAN}

Penulis menganggap, dengan dibuatnya tagline baru yang dipelopori oleh pemerintah daerah terhadap kabupaten Kuantan singingi, yakni KUANSING TANAH SURGA (Land of Paradise), tanah surga memiliki makna bahwa Kabupaten Kuantan Singingi memiliki beragam objek wisata yang dipadukan menjadi satu. Objek wisata tersebut seperti wisata alam, budaya, kuliner, sejarah, petualangan, dan masih banyak yang lainnya. Selain itu, pemilihan kata surga juga dikarenakan pesona alam yang membentang luas. Namun, menurut penulis, bila dipadukan menjadi satu kesatuan, peluncuran tagline dan logo baru tersebut tidak semerta-merta dapat menutupi icon pacu jalur sebagai komoditas utama dari pariwisata Kabupaten Kuantan Singingi.

\section{DAFTAR PUSTAKA}

[1] Adisaputro, G. (2010). Manajemen Pemasaran: Analisis Untuk Perancangan Strategi Pemasaran. Sekolah Tinggi Ilmu Manajemen YKPN.

[2] Agung, L. (2011). "Character Education Integration in Social Studies Learning." International Journal of History Education, 12 Nomor 2, 392-403.

[3] Anholt, S. (2007). Competitive Identity: The New Brand Management For Nations, Cities And Regions. Palgrave Macmillan.

[4] Badan Ekonomi Kreatif. (2018). Kolase Pemikiran Ekonomi Kreatif. CV. Oxy Consultant.

[5] Baiquni, D. M. D. W. (2011). Perencanaan Dan Pengembangan Pariwisata. CV Lubuk Agung. 
[6] Belch, G. E. (2004). Advertising \& Promotion: An Integrated Marketing Communication Perspective/George E. Belch; Michael A. Belch. Mcgraw Hill.

[7] Cannon, J. P. (2008). Pemasaran Dasar: Pendekatan Manajerial Global Basic Marketing: A Global Managerial Approach. Salemba.

[8] Damanik, J. (2013). Pariwisata Indonesia. Pustaka Pelajar.

[9] Damardjati, R. (2001). Istilah-Istilah Dunia Pariwisata (Cetakan Keenam). Pradnya Paramita.

[10] Djaslim, S. (2003). Manajemen Pemasaran. Linda Karya.

[11] Eriyanto. (2011). Analisis Isi: Pengantar Metodologi untuk Penelitian Ilmu Komunikasi dan Ilmuilmu Sosial Lainnya. Kencana.

[12] Evans, J. R. (1994). Berpikir Kreatif Dalam Pengambilan Keputusan Dan Manajemen. Bumi Aksara.

[13] Hamidati, Anis, dkk. (2011). Komunikasi 2.0 Teoritisasi dan Implikasi. Mata Padi Pressindo.

[14] Ismandianto, Belli Nasution, E. E. L. (2020). Model Komunikasi Pariwisata Religi Dalam Pengembangan Wisata Kabupaten Rokan Hulu. Pesona, 5 Nomor 2. http://jurnal.unmer.ac.id/index.php/jpp/article/view/4644

[15] Ismandianto. (2019). Model Komunikasi Pemerintahan Kota Tanjung Pinang dalam Pengembangan Wisata Pulau Penyengat Kepulauan Riau. Jurnal Nahkoda, 21-34.

[16] Karyono, H. (1997). Kepariwisataan. PT Grafindo.

[17] Kasali. (1998). Membidik Pasar Indonesia: Segmentasi,Targeting,Positioning. PT Gramedia.

[18] Kertajaya, H. (2008). Arti Komunitas. Gramedia Pustaka Utama.

[19] Kotler, P. D. G. A. (2004). Dasar-Dasar Pemasaran Jilid 2. Indeks.

[20] Kotler, P. D. K. L. K. (2009). Manajemen Pemasaran Jilid 2. Erlangga.

[21] Landry, C. (2008). The Creative City: A Toolkit For Urban Innovators. Comedia.

[22] Larasati, D. (2016). Potensi Wisata dalam Pembentukan City Branding Kota Pekanbaru. Komunikasi, 10, Nomor, 99-116. https://doi.org/https://doi.org/10.20885/komunikasi.vol10.iss2.art1

[23] Mccarthy Dan Perreault. (2009). Intisari Pemasaran. Salemba.

[24] Meitaliza, Y. (2018). Strategi Komunikasi Dinas Kebudayaan dan Pariwisata Kabupaten Kuantan Singingi dalam Mengembangkan Brand Destination Pacu Jalur. JOM FISIP, 5 Edisi 2, 1-15. 
[25] Morrisan. (2010). Periklanan: Komunikasi Pemasaran Terpadu. Kencana.

[26] Muhammad, A. (2009). Cara Pintar Promosi Murah Dan Efektif. Garailmu.

[27] Mulyana, D. (2003). Metodologi Penelitian Kualitatif. Remaja Rosdakarya.

[28] Patton, M. Q. (2002). Qualitative Research And Evaluation Methods (3rd ed.). Sage Publications. Inc.

[29] Pitana, I. G. D. I. K. S. D. (2009). Pengantar Ilmu Pariwisata. Andi.

[30] Puspitasari, A. (2010). Blog dan Media Sosial Panduan untuk Guru era Baru. Acer Indonesia.

[31] Romli, R. D. (2020). Implementasi strategi komunikasi "Bandung Juara" sebagai bagian dari city branding Kota Bandung. PRofesi Humas, 4 Nomor 2, 263-289. https://doi.org/https://doi.org/10.24198/prh.v4i2.23547

[32] Siswanto Dan Kleinsteuber, F. (2002). Strategi Manajemen Pemasaran. Damar Melia Pustaka.

[33] Soemanegara, R. (2006). Strategic Marketing Communication-Konsep Strategis Dan Terapan. Alfabeta.

[34] Sugiarsono, J. (2009). City branding Bukan Sekedar membuat Logo dan Slogan. Majalah SWA.

[35] Sugiyono. (2016). Memahami Penelitiaan Kualitatif. Alfabeta.

[36] Sulaksana, U. (2003). Integrated Marketing Communication. Pustaka Pelajar.

[37] Suyanto, M. (2007). Marketing Strategy Top Brand Indonesia. Andi.

[38] Syahbana, Boy, M. Rahmat Yananda, Rheinatus Beresaby, R. H. \& U. S. (2014). Branding Tempat: Membangun Kota, Kabupaten, Dan Provinsi Berbasis Identitas. Makna Informasi.

[39] Tjiptono, F. (2002). Strategi Pemasaran. Andi.

[40] Toynbee, A. J. (1961). A Study Of History. Oxford University Press.

[41] Vani. (2020). Model Pentahelix Dalam Mengembangkan Potensi Wisata di Kota Pekanbaru. Ilmu $\begin{array}{llclll}\text { Administrasi Publik } & \text { UMA, } & 8 & \text { Nomor } & 1, & 63-70 .\end{array}$ https://doi.org/https://doi.org/10.31289/publika.v8i1.3361

[42] Yasir dkk. (2019). Kebijakan komunikasi dalam membangun destinasi dan masyarakat sadar wisata di kabupaten bengkalis. Studi Komunikasi, $3, \quad 424 \quad$ - 443. https://doi.org/http://dx.doi.org/10.25139/jsk.v3i3.1548 